\title{
Effect of two-stage thermal disintegration on particle size distribution in sewage sludge
}

\author{
Anna M. Karczmarek, Jerzy Gaca* \\ University of Technology and Life Sciences in Bydgoszcz, Faculty of Technology and Chemical Engineering, \\ ul. Seminaryjna 3, 85-326 Bydgoszcz, Poland \\ *Corresponding author: e-mail: jerzy.gaca@utp.edu.pl
}

\begin{abstract}
The effect of two-stage thermal disintegration of sewage sludge on the particle size distribution using laser diffraction method has been studied. The sludge was sampled from municipal sewage treatment plant after each stage of disintegration. The first stage of disintegration known as homogenization proceeds at temperature of $70-90^{\circ} \mathrm{C}$ and pressure of $3 \mathrm{bar}$, the second stage called thermal hydrolysis was performed at temperature of $160-170^{\circ} \mathrm{C}$ and pressure of 6 bar. It was found that the first stage of disintegration has the strongest impact on the reduction of the sludge particle size and changes in chemical properties. The maximum size of the particles from raw sewage before disintegration was $310 \mu \mathrm{m}$. After first stage of the process average size of the particles was $250 \mu \mathrm{m}$, and during the second stage it was reduced to $226 \mu \mathrm{m}$. Sludge disintegration degree $\left(\mathrm{DD}_{\mathrm{COD}}\right)$ of $59 \%$ confirms high effectiveness of the process. We established that the redox potential (Eh) of sludge effluents was changed after each step of the studied process. Furthermore, chemical oxygen demand (COD) increases which leads to the conclusion that resizing of floccules is accompanied by hydrolysis.
\end{abstract}

Keywords: laser diffraction, particle size distribution, sludge, thermal hydrolysis.

\section{INTRODUCTION}

A very commonly used method for the sewage sludge stabilization is methane fermentation. The efficiency of this process depends on many factors, among others on the characteristics of sewage sludge. The ratio of the primary to excessive sludge in the mixture directed to the process of anaerobic digestion and the pollution load index usually expressed as chemical oxygen demand (COD) significantly affect the course of stabilization. It is known that the step limiting rate of the anaerobic digestion process is hydrolysis of macromolecular organic compounds. That is why, processes of sewage sludge pre-treatment prior to fermentation are applied more and more often. The most commonly used procedures are mechanical methods, use of ultrasounds, high temperature, acids and alkalis, ozone and enzymatic methods. The pre-treatment processes are intended to destroy the structure of sludge floccules, disrupt microbial cell walls and release the cell content into sludge liquid. Furthermore, the decomposition of macromolecular compounds to monomers and dimmers can also occur ${ }^{1}$. This treatment increases the availability for microorganisms the methanogenic substrates supplied with sludge. It results in shorter time of fermentation, increase of biogas production and improvement of dewatering. In order to evaluate the efficiency of each stage of the sludge thermal disintegration, analysis of particle size distribution was applied. Different methods are used to measure particle size, including the use of sieves and filters, sedimentation or microscopic methods and other ${ }^{4,6}$. The measurement of particle size by laser diffraction method was employed for testing the changes in flock size during flocculation in active sludge ${ }^{7}$, studies on the effect of ultrasounds application for disinfection of sludge $^{8}$, determination of dependence between particle size and dewatering ${ }^{2,3}$, investigations of sedimentation of suspended solids ${ }^{5,9,10,15}$ and other.
The aim of this study was to investigate the effect of each stage of thermal disintegration performed in an industrial installation on change in size of sludge particles and change in chemical oxygen demand (COD), total organic carbon (TOC) and redox potential $\left(\mathrm{E}_{\mathrm{h}}\right)$ and degree of disintegration $\left(\mathrm{DD}_{\mathrm{COD}}\right)$. The study was focused on analyzing the effect of thermal disintegration of sludge on particle size distribution after the stages of homogenization and thermal hydrolysis.

\section{METHODS}

Sewage sludge was sampled from the local sewage treatment plant from an installation for sludge pre-treatment before methane fermentation process. The technological installation in which disintegration is carried out consists of several apparatuses. In the silos the previously mixed and thickened to a dry matter content of $16 \pm 2 \%$ primary and excessive sludge is stored. At the first stage of disintegration, the sludge from the silos is pumped to the homogenizer in which the sludge is heated by steam to about $90^{\circ} \mathrm{C}$ under the pressure of 3 bars. The retention time is about $1.5 \mathrm{~h}$. After homogenization the sludge is transported to a hydrolysis reactor and warmed for 20-30 min to $160-170^{\circ} \mathrm{C}$ under 6 bars of pressure. Then, the sludge is cooled to about $100^{\circ} \mathrm{C}$, depressurised to atmospheric pressure in an expansion vessel and finally directed to a fermentation chamber. The samples were collected from four locations, 1 - silos, 2 - sludge after homogenization, 3 - expansion vessel (sludge after second stage of disintegration), 4 - sludge after fermentation and placed in polyethylene containers. The determinations were performed immediately after delivery of the samples to laboratory. Samples were collected in five series at weekly intervals. The determination were performed immediately after delivery of samples to laboratory. Samples were collected in five series.

The particle size distribution was determined using a laser meter of particle size, Fritsch Analysette 22 
Micro Tec plus with the MaScontrol software suitable to control the course of the measurements, processing the collected data and calculating the arithmetic mean, geometric mean, root mean square, median value, modal value, specific surface, volume weighted average diameter $\mathrm{D}[4,3]$ and other statistical parameters. In this study we investigated the relationship between the specific surface area and average particle size. The specific surface area defined as the ratio of the surface area to volume is an important parameter affecting the physical and chemical properties of the particles (e.g. sorption). Average particle size was expressed in terms of volume weighted average diameter D [4,3]. Laser diffraction method does not require a number of particles in order to provide the average result and hence the value of $\mathrm{D}[4,3]$ can be calculated from equation:

$\mathrm{D}[4,3]=\frac{\sum d^{4}}{\sum d^{3}}$

where: $d$ denotes diameter of a particle.

It allows measurement of particle size within the range from 0.08 to $2000 \mu \mathrm{m}$ and the use of ultrasounds during the measurements ( $36 \mathrm{kHz}$ ultrasonic bath, $60 \mathrm{~W})$. Prior to the introduction of sample into the measuring chamber, each sample was diluted with deionised water ( $1 \mathrm{~g}$ of sample in $10 \mathrm{ml}$ of deionised water). In order to avoid flocculation of sludge particles and to provide their uniform distribution in the measuring chamber surface tension reducing agent Dusazin 901 (Fritsch) was added. Then the mixture was stirred for $10 \mathrm{~min}$. From 1 to $2 \mathrm{ml}$ of a suspension prepared from sludge was dosed into the sample dispergation system until appropriate absorption of the stream was achieved. Each measurement was carried out in 3 repetitions. Automatic computational model according to the Fraunhofer theory was selected for the calculations of the particle size distribution. The determination of the total organic carbon (TOC) was carried out by the use of Sievers InnovOx apparatus (GE Analytical Instruments) (PN-EN 1484:1999) with application of Super Critical Water Oxidation. Chemical oxygen demand (COD) was determined by dichromate method (PN-ISO 6060:2006). The determinations of COD and TOC were performed using the samples reduced in size by the homogenizer (H 500 Pol-Eko Aparatura).

Volatile fatty acids (VFA) assay in sewage sludge was performed using the steam distillation method (PN-C04616-04:1975).

The degree of disintegration $\left(\mathrm{DD}_{\mathrm{COD}}\right)$ was determined from the relationship between the concentration of organic compounds dissolved in sludge samples subjected to alkaline hydrolysis $\left(\mathrm{NaOH} 0.5\right.$ mole $\left(\mathrm{dm}^{3}\right)^{-1}$ for $22 \mathrm{~h}$ at the temperature of $20^{\circ} \mathrm{C}$ ) and the content of these compounds in sludge subjected to thermal disintegration $^{11-13}$. Content of dissolved organic compounds was accepted as COD value in samples filtered through a filter with pore size of $0.45 \mu \mathrm{m}$. The percentage of the degree of disintegration was calculated according to the equation below:

$\mathrm{DD}_{\mathrm{COD}}=\frac{\mathrm{COD}_{\mathrm{TH}}-\mathrm{COD}_{0}}{\mathrm{COD}_{\mathrm{NaOH}}-\mathrm{COD}_{0}} \cdot 100[\%]$

where: $\mathrm{COD}_{\mathrm{TH}}-\mathrm{COD}$ of sludge filtrate after thermal hydrolysis $\left[\mathrm{mg} \cdot\left(\mathrm{dm}^{3}\right)^{-1}\right], \mathrm{COD}_{0}-\mathrm{COD}$ of raw sludge filtrate $\left[\mathrm{mg} \cdot\left(\mathrm{dm}^{3}\right)^{-1}\right], \mathrm{COD}_{\mathrm{NaOH}}-\mathrm{COD}$ of sludge filtrate after alkaline hydrolysis $\left[\mathrm{mg} \cdot\left(\mathrm{dm}^{3}\right)^{-1}\right]$.

The multifunctional device Elmetron CX-501 and electrode ERPt-13 (Hydromet) were used to determine redox potential.

The dry residue was determined by drying the sample to the constant weight at $105^{\circ} \mathrm{C}$. The $\mathrm{pH}$ was determined by a potentiometric method using the multifunctional device Elmetron CX-501 and the electrode ERH-11S (Hydromet).

\section{RESULTS AND DISCUSSION}

Sewage sludge sampled during the whole period of the studies was characterized by significantly different concentrations. The range of variability of the individual indexes is summarized in Table 1.

Fig. 1 shows a typical particle size distribution for the raw sludge (dQ3(x)-density distribution, Q3(x)-the sum of the distribution). The distribution is monomodal and its maximum is shifted to larger particles. It was found that in the raw sludge, the particles' size ranges from $0.3 \mu \mathrm{m}$ to $310 \mu \mathrm{m}$. The particles with the size between 50-60 $\mu \mathrm{m}$ represent the largest percentage. The distribution chart shows that $50 \%$ of the particles have a size of about $60 \mu \mathrm{m}$ and approximately the size of $90 \%$ of particles does not exceed $140 \mu \mathrm{m}$.

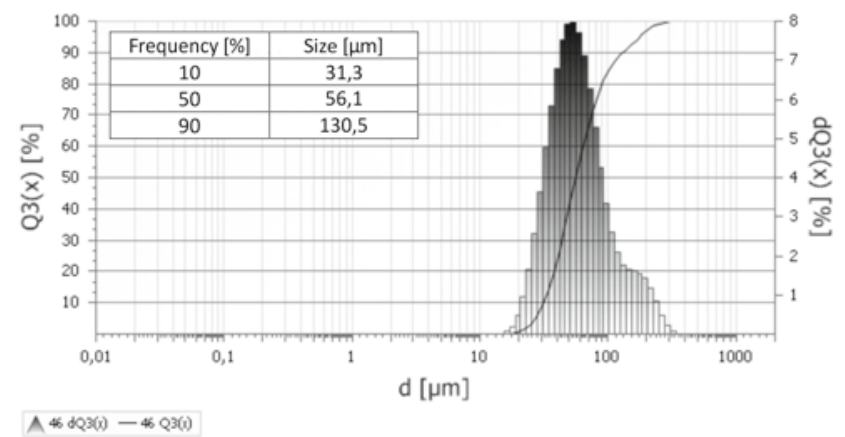

Figure 1. Example of particle size distribution in raw sludge, (beam obscuration: $9.00 \%$ )

The first stage of disintegration results in the reduction of particle size to the upper limit of $250 \mu \mathrm{m}$ (Fig. 2). Generally after disintegration the particle size distribution is monomodal and exhibits skewness toward small particles. In some cases density distribution curve is bimodal and size-class of smaller particles can be

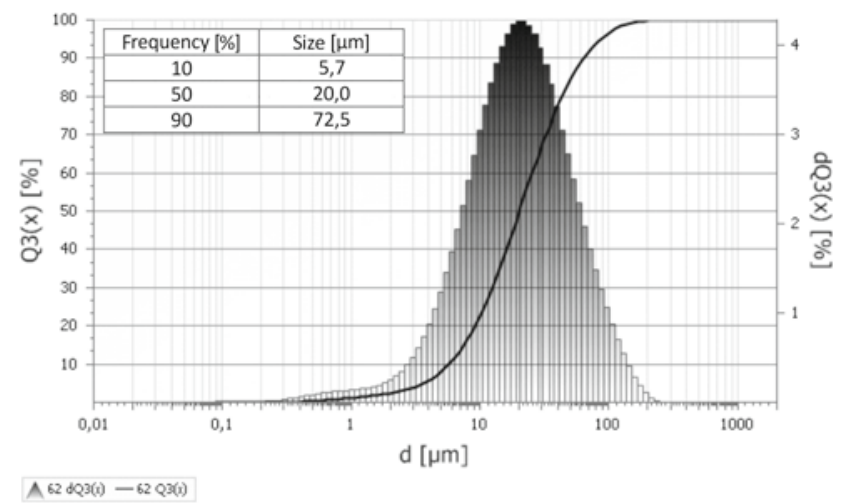

Figure 2. Example of particle size distribution in sludge after the I-st stage of thermal disintegration (beam obscuration: $16.00 \%$ ) 
Table 1. Parameters of sludge

\begin{tabular}{|l|c|c|c|c|}
\hline Type of sludge/index & Raw sludge & $\begin{array}{c}\text { I-st stage of } \\
\text { disintegration }\end{array}$ & $\begin{array}{c}\text { II-nd stage of } \\
\text { disintegration }\end{array}$ & After fermentation \\
\hline pH & $5.9-6.2$ & $6.0-6.5$ & $5.4-6.4$ & $6.9-7.5$ \\
\hline Dry solid $(\%)$ & $8.25-15.95$ & $9.8-13.8$ & $5.9-8.35$ & $3.05-5.4$ \\
\hline COD $\left(\mathrm{g}^{-1}\right)$ & $899.4-2243.4$ & $932.2-1163.3$ & $996.2-1270.1$ & $186.6-880.6$ \\
\hline VFA $\left(\mathrm{mg}^{-1} \mathrm{~kg}^{-1}\right)$ & $1380-1884$ & $492-1608$ & $432-1020$ & $144-1500$ \\
\hline TOC $\left(\mathrm{g} \cdot \mathrm{kg}^{-1}\right)$ & $210.3-544.3$ & $214.9-381.0$ & $252.8-394.1$ & $42.5-195.7$ \\
\hline
\end{tabular}

COD - Chemical Oxygen Demand; VFA - Volatile Fatty Acid; TOC - Total Organic Carbon

distinguished. Density distribution curve shows that the largest percentage of the particles is about the size of $20-30 \mu \mathrm{m}$. It was found that $50 \%$ of particles have the size of about $20 \mu \mathrm{m}$ and the size of $90 \%$ of particles does not exceed $75 \mu \mathrm{m}$. The second stage cause further reduction of particle size upper limit to $220 \mu \mathrm{m}$ (Fig. 3).

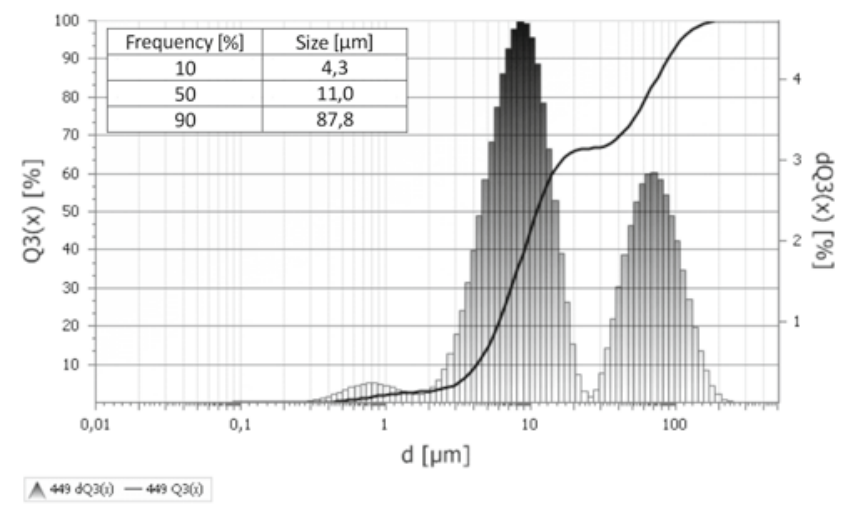

Figure 3. Example of particle size distribution in sludge after the II-st stage of thermal disintegration (beam obscuration: $11.00 \%$ )

In the case of sludge after the hydrolysis density distribution curve assumes a characteristic shape which allows to distinguish three groups of particle size. The first group contains the particles of the size ranging from 0.3 to $1.5 \mu \mathrm{m}$. The second group, which is the most numerous consists of particles with the size between 1.5 to 30 $\mu \mathrm{m}$. In the third group the particles size is in the range of 30-220 $\mu \mathrm{m}$. It is worth emphasizing that the size of $50 \%$ of particles does not exceed $15 \mu \mathrm{m}$ and $90 \%$ of the particles have the size less than $95 \mu \mathrm{m}$. We found that the fermentation process caused a significant reduction of particle size, which ranges from 0.3 to $120 \mu \mathrm{m}$ (Fig. 4). The distribution of particle sizes is monomodal and the largest percentage are the particles of the size ranging from 9 to $10 \mu \mathrm{m}$. It is worth noting that $50 \%$ of particles have a size less than $10 \mu \mathrm{m}$ similarly as in the case of the second stage of disintegration and $90 \%$ of all the particles are those with the size of less than $20 \mu \mathrm{m}$. However, the most commonly occurring particle size (mode) is similar to the size of sludge particles after the first and the second stage of disintegration. The

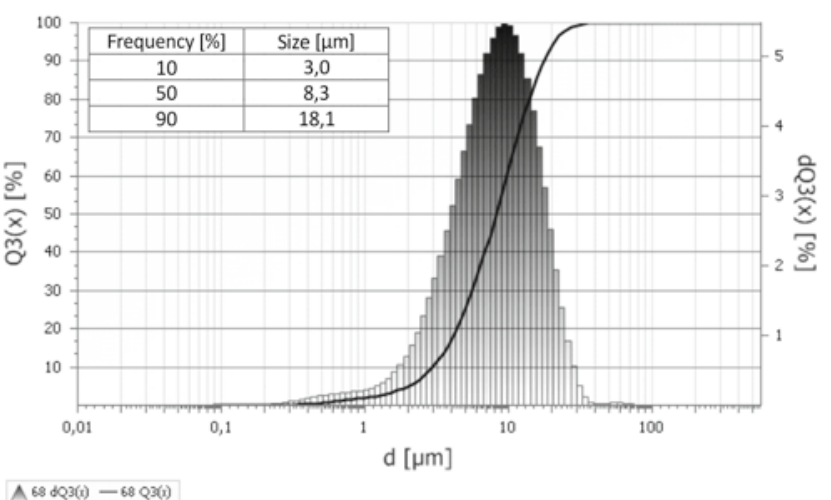

Figure 4. Example of particle size distribution in sludge after fermentation (beam obscuration: $10.00 \%$ )

values of particle sizes measured for individual stages of sewage treatment are presented in Table 2.

Application of ultrasounds during measurement of particle size was also analyzed. According to the user manual of apparatus, in order to ensure a uniform distribution of particles in the measuring chamber and to prevent aggregation of sludge flocs, the test sample should be subjected to the action of ultrasounds before measurement. In order to determine whether the ultrasounds applied in the apparatus have an influence on particle size, the studies on the effect of different ultrasound power $(0 \%, 50 \%$ and $100 \%)$ on particle size of sludge were conducted (Table 3). It was found that use of ultrasounds both in the case of raw sludge and sludge after hydrolysis slightly affects the results. In the case of raw sludge, average particle sizes at $100 \%$ of ultrasonic power were lower by $8-9 \%$ in comparison with measurements without use of ultrasounds. In the case of sludge after thermal hydrolysis, effect of ultrasounds applied during analysis was less significant. The average particle size decreased by $4.5 \%$ in sludge where $100 \%$ of the ultrasonic power of ultrasound was used with respect to sludge which were not exposed to ultrasound. Therefore, ultrasounds were not applied in the presented studies.

Moreover, correlation between average particle size and specific surface area was observed (Fig. 5). The average values $(n=5)$ of both parameters determined for raw sewage sludge, for the sludge after disintegration stages and for sludge after fermentation are summarised

Table 2. Minimum, maximum and most often (mode) values for particle size distribution in sludge studied; average values of 5 repetitions

\begin{tabular}{|l|c|c|}
\hline Type of sludge & $\begin{array}{c}\text { Minimum } \\
{[\mu \mathrm{m}]}\end{array}$ & $\begin{array}{c}\text { Maximum } \\
{[\mu \mathrm{m}]}\end{array}$ \\
\hline Raw sludge & 0.5 & 310 \\
Sludge after I stage of disintegration & 0.3 & 250 \\
Sludge after II stage of disintegration & 0.3 & 226 \\
Sludge after fermentation & 0.3 & 11 \\
\hline
\end{tabular}


Table 3. Effect of ultrasounds applied during measurement on average particle size in raw sludge and after the II-nd stage of thermal disintegration

\begin{tabular}{|l|c|c|}
\hline \multirow{2}{*}{$\begin{array}{l}\text { Ultrasonic } \\
\text { power }\end{array}$} & \multicolumn{2}{|c|}{ Average particle size $[\mu \mathrm{m}]$} \\
\cline { 2 - 3 } & Raw sludge & $\begin{array}{c}\text { Sludge after the II-nd stage of } \\
\text { disintegration }\end{array}$ \\
\hline Off $(0 \%)$ & 56.9 & 30.6 \\
\hline $50 \%$ & 50.6 & 30.1 \\
\hline $100 \%$ & 52.1 & 29.3 \\
\hline
\end{tabular}

in Table 4. We found that during all stages of sludge processing particle sizes are decreasing gradually with increasing the specific surface. This suggest that the particles of raw sludge has a regular shape and their surface is smooth. On the other hand, after disintegration the surface is porous and irregular. In the case of raw sludge, a strong dependence between these parameters is observed i.e. as the average particle size is reduced, their specific surface area increases. In this case, the linear correlation coefficient $\mathrm{R}^{2}$ is equal to 0.9742 . However, in the case of sludge after the second stage of thermal disintegration, $\mathrm{R}^{2}$ is 0.6303 .

Table 4. Mean values of the average particle size and specific surface area, $\mathrm{n}=5$

\begin{tabular}{|l|c|c|}
\hline Sludge/parameter & $\begin{array}{c}\text { Average } \\
\text { particle size } \\
{[\mu \mathrm{m}]}\end{array}$ & $\begin{array}{c}\text { Specific } \\
\text { surface area } \\
\mathrm{cm}^{2} \cdot \mathrm{cm}^{-3}\end{array}$ \\
\hline Raw sludge & 58.8 & 1257 \\
\hline $\begin{array}{l}\text { Sludge after the I-st stage of } \\
\text { disintegration }\end{array}$ & 36.9 & 5567 \\
\hline $\begin{array}{l}\text { Sludge after the II-st stage of } \\
\text { disintegration }\end{array}$ & 16.7 & 9887 \\
\hline Sludge after fermentation & 10.6 & 10800 \\
\hline
\end{tabular}

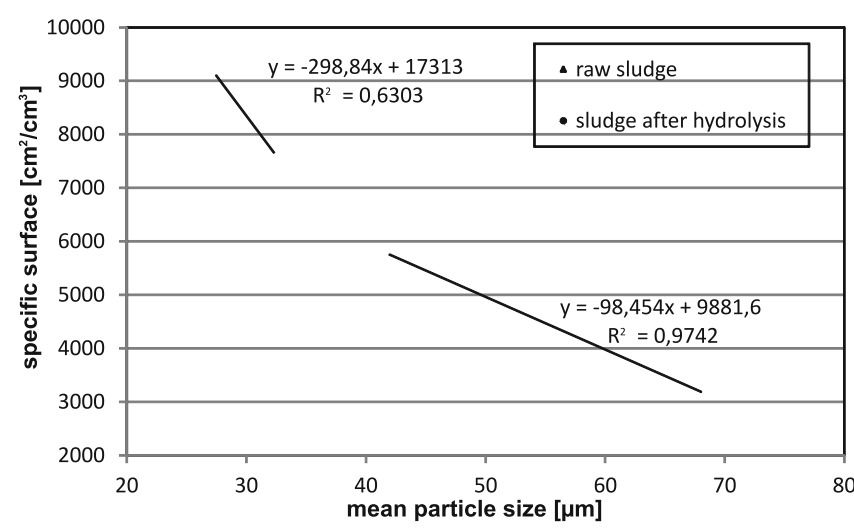

Figure 5. Correlation between average particle size and specific surface area for raw sludge and sludge after the II-nd stage of disintegration

The degree of sludge disintegration $\left(\mathrm{DD}_{\mathrm{COD}}\right)$ after the second stage of thermal disintegration was within the range from 51 to $66 \%$. The average value obtained from five test series was $59 \%$. According to many authors ${ }^{11-13}$, ultrasound method leads to the disintegration degree ranging from 5 to $40 \%$ depending on the frequency and exposure time of sonication. As we established, the redox potential of sludge effluents in all the stages of thermal disintegration is negative. These conditions are determined by the presence of reducing agents (electron donors), which are organic matter and other organic compounds and reduced inorganic compounds $\left(\mathrm{NH}_{4}^{+}, \mathrm{Fe}^{2+}, \mathrm{Mn}^{2+}, \mathrm{S}^{2-}, \mathrm{CH}_{4} \text { and } \mathrm{H}_{2}\right)^{14}$. The values of redox potential $\left(\mathrm{E}_{\mathrm{h}}\right)$ were as follows: for the effluents obtained from raw sludge $-269.9 \mathrm{mV}$, for the sludge after the first stage of disintegration $-50.4 \mathrm{mV}$, for the sludge after the second stage of disintegration $-18.5 \mathrm{mV}$ and for the sludge after methane fermentation $-146.3 \mathrm{mV}$, respectively. Increase in redox potential after the first and the second stage of disintegration proves that the content of substances with oxidizing properties increased in effluents. The amount of reducing agents (organic compounds expressed by COD, which are reducing agents) decreases and therefore, reducing potential decreases (increase of redox potential). In the case of the effluents after methane fermentation, the redox potential is much lower compared to the sludge after the thermal disintegration, which is caused by the anaerobic conditions in the fermentation chamber and the presence of fermentation products $\mathrm{CH}_{4}$ and $\mathrm{CO}_{2}$.

\section{CONCLUSIONS}

The paper presents results of a two-step process of thermal disintegration of sludge. As a result of studies, several changes in properties of sewage sludge during successive stages of processing were observed.

Thermal disintegration reduces the maximum particle size from $310 \mu \mathrm{m}$ to $250 \mu \mathrm{m}$ after the first stage and to $220 \mu \mathrm{m}$ after the second stage of disintegration, respectively. Simultaneously, the process of disintegration significantly reduces the size of the most common particles from $80 \mu \mathrm{m}$ in raw sewage to about $10 \mu \mathrm{m}$ in sludge after thermal disintegration. Application of ultrasounds in the analytical procedure for the determination of particle size results in their reduction in comparison with the determinations without ultrasounds. Correlation between the average particle size and specific surface area was observed. As the particle size was reduced, the particle surface was increased in sludge. This tendency is more important in the case of raw sewage than in the case of sludge after thermal disintegration. It is worth noting that after first and second stages of disintegration redox potential increases in comparison with raw sludge which can be caused by the organic compounds concentration decreasing expressed in terms of COD parameter. As it was found, disintegration degree, ranges from $51-66 \%$ and the average value is $59 \%$.

\section{ACKNOWLEDGEMENT}

The project was realized under own research project N N523 634338.

\section{LITERATURE CITED}

1. Appels, L., Baeyens, J., Degreve, J. \& Dewil, R. (2008). Principles and potential of the anaerobic digestion of waste-activated sludge. Progress in Energy and Combustion Science, 34 (6), 755-781. DOI: 10.1016/j.pecs.2008.06.002.

3. Friedrich, E., Friedrich, H., Heinze, W., Jobst, K., Richter, H.J. \& Hermel, W. (1993). Progress in characterization of sludge particles. Wat. Sci. Tech., 28 (I), 14S-148. 0273-1223193.

4. Olböter, L. \& Vogelpohl, A. (1993). Influence of particle size distribution on the dewatering of organic sludges. Wat. Sci. Tech. 28 (1), 149-157. 0273-1223193.

5. Neis, U. \& Tiehm, A. (1997). Particle size analysis in primary and secondary waste water effluents. Wat. Sci. Tech. 36 (4), 151-158. 
6. Tiehm, A., Herwig, V. \& Neis, U. (1999). Particle size analysis for improved sedimentation and filtration in waste water treatment. Wat. Sci. Tech. 39 (8), 99-106.

7. Barth, H.G. \& Flippen, R.B. (1995). Particle Size Analysis. Anal. Chem, 67(12), 257-272. Publication Date: June 1995. DOI: $10.1021 / \mathrm{ac} 00108 \mathrm{a} 013$.

8. Biggs, C.A. \& Lant, P.A. (2000). Activated sludge flocculation: on-line determination of floc size and the effect of shear. Wat. Res. 34 (9), 2542-2550.

9. Blume, T. \& Neis, U. (2004). Improved wastewater disinfection by ultrasonic pre-treatment. Ultrasonics Sonochemistry, 11 (5), 333-336. Available online August 2003. DOI: 10.1016/ S1350-4177(03)00156-1.

10. Chaignon, V., Lartiges, B.S., El Samrani, A. \& Mustin, C. (2002). Evolution of size distribution and transfer of mineral particles between flocs in activated sludges: an insight into floc exchange dynamics. Wat. Res. 36 (3), 676-84.

11. Houghton, J.I., Burgess, J.E. \& Stephenson, T. (2002). Off-line particle size analysis of digested sludge. Wat. Res., 36 (18), 4643-7.

12. Jung, Y., Ko, H., Jung, B. \& Sung, N. (2011). Application of Ultrasonic System for Enhanced Sewage Sludge Disintegration: A Comparative Study of Single- and Dual- Frequency, KSCE Journal of Civil Engineering, 15 (5), 793-797. DOI: 10.1007/s12205-011-0832-6.

13. Tiehm, A., Nickel, K., Zellhorn, M. \& Neis, U. (2001). Ultrasonic waste activated sludge disintegration for improving anaerobic stabilization. Wat. Res., 35 (8), 2003-9. Web: www. elsevier.com/locate/watres.

14. Huan, L., Yiying, J., Mahar, R.B., Zhiyu, W. \& Yongfeng, N. (2009). Effects of ultrasonic disintegration on sludge microbial activity and dewaterability. Journal of Hazardous Materials, 161 (2-3), 1421-6. DOI: 10.1016/j.jhazmat.2008.04.113.

15. DeLaune, R.D. \& Reddy, K.R. (2005). Redox potential. Encyclopedia of Soils in the Environment, 366-371. Web: http:// www.sciencedirect.com/science/article/pii/B0123485304002125.

16. Wu, J. \& He, C. (2010). Experimental and modeling investigation of sewage solids sedimentation based on particle size distribution and fractal dimension. Int. J. Environ. Sci. Tech. 7 (1), 37-46. 